\title{
Review of the state of knowledge of crayfish species in the lberian Peninsula
}

\author{
Iván Vedia* and Rafael Miranda \\ Department of Environmental Biology, University of Navarra, Irunlarrea 1, E-31008 Pamplona, Navarra, Spain. \\ *Corresponding author: ivedia@alumni.unav.es
}

Received: 22/11/12

Accepted: 21/6/13

\begin{abstract}
Review of the state of knowledge of crayfish species in the Iberian Peninsula

This paper reviews information relevant to managing the four crayfish species present in the Iberian Peninsula. The red swamp crayfish, Procambarus clarkii, signal crayfish, Pacifastacus leniusculus, and Yabbie, Cherax destructor, are classified as invasive alien species by Spanish legislation. The most significant negative impacts of these species in freshwater ecosystems are noted, and some management methods are proposed. In addition, scientific studies addressing the origin and taxonomy of the Iberian white-clawed crayfish, Austropotamobius italicus italicus, are discussed. The Iberian populations of A. $i$. italicus have been severely diminished since the onset of the expansion of the aphanomycosis disease in 1978. However, this trend began to undergo reversal a few years ago, and the populations of this species are now growing. Finally, current legislation concerning the fishing and conservation of crayfish species is explained and discussed.
\end{abstract}

Key words: Austropotamobius italicus, Procambarus clarkii, Pacifastacus leniusculus, Cherax destructor, invasive species, aphanomycosis, fishing regulations.

\section{RESUMEN}

\section{Revisión del estado de conocimiento de las especies de cangrejo de río en la Península Ibérica}

En este artículo se ha hecho una profunda revisión de toda la información relevante para la gestión de las cuatro especies de cangrejo de río presentes en la Península Ibérica. El cangrejo rojo de las marismas Procambarus clarkii, el cangrejo señal Pacifastacus leniusculus y el cangrejo Yabbie Cherax destructor son consideradas especies exóticas invasoras en la legislación española. Se mencionan los impactos negativos más significativos que estas especies están produciendo sobre los ecosistemas acuáticos y se proponen algunos métodos de gestión. Por otro lado, se exponen los diferentes estudios científicos relacionados con el origen y taxonomía del cangrejo de río que habita en la Península Ibérica (Austropotamobius italicus italicus). Las poblaciones ibéricas de A. i. italicus están muy debilitadas a causa de la enfermedad de la afanomicosis que comenzó a expandirse a partir del año 1978. Aunque esta tendencia cambió hace unos pocos años y las poblaciones están creciendo. Finalmente, se explica y discute la legislación vigente relativa a la conservación y pesca de las especies de cangrejos de río.

Palabras clave: Austropotamobius italicus, Procambarus clarkii, Pacifastacus leniusculus, Cherax destructor, especies invasoras, afanomicosis, legislación pesquera.

\section{INTRODUCTION}

The increasing spread of invasive alien species on a global scale is one of the most serious prob- lems facing global biodiversity. In fact, invasive alien species are considered the second most significant cause of extinctions after habitat destruction (IUCN, 2011). This problem not only affects 
biodiversity but also leads to economic, health and social problems.

Aquatic ecosystems are particularly vulnerable to the introduction of invasive alien species. Fifty percent of the invasive species present in the Iberian Peninsula are fishes and crayfishes. In the inland waters of the Iberian Peninsula, in particular, there are at least 45 invasive invertebrate species and 28 invasive vertebrate species (García-Berthou, 2007). Of the 45 invasive species of invertebrates, three are crayfish. These three non-native crayfish species are the red swamp crayfish, Procambarus clarkii, signal crayfish, Pacifastacus leniusculus, and Yabbie, Cherax destructor.

Crayfishes are considered keystone species because they play an important ecological role in freshwater ecosystems. The influence of these crustaceans on ecosystems is more important than might be expected considering their relative abundance or total biomass. These species occupy a central position in the food chains of many ecosystems, simultaneously acting as both prey and predators (Geiger et al., 2005). Crayfishes constitute one component of the connecting link between aquatic and terrestrial ecosystems, facilitating the energy flow between them (Larson \& Olden, 2011).

In addition, crayfishes play an important economic and social role. For example, in some areas, such as the Guadalquivir marshes, the red swamp crayfish represents an important food resource, and its trade provides an extra contribution to the local economy (Cano \& Ocete, 1994). Additionally, recreational crayfish fishing is deeply rooted in local culture (Alonso et al., 2000).

The specific goals of this paper are as follows: 1) to review the current knowledge of crayfishes in the Iberian Peninsula by describing the main characteristics of native and alien crayfishes in terms of their origin, taxonomy, distribution range and associated impacts; 2) to analyse and evaluate the ecological function performed by crayfish in aquatic ecosystems; 3 ) to note some commercial, economic and production-related information about crayfish; and 4) to review the existing legislation addressing the management of all crayfish species present in the Iberian
Peninsula and assess its implications for aquatic ecosystem conservation.

In summary, the principal aim of this paper is to analyse the current knowledge regarding the conservation status of crayfish conservation status in the Iberian Peninsula to develop a better set of scientific criteria with which to implement adequate management policies.

\section{MATERIALS AND METHODS}

The Iberian Peninsula is a geographically isolated area located in southwestern Europe. It is surrounded by the Mediterranean Sea and Atlantic Ocean and is connected to the rest of Europe by the Pyrenees in the northeast. The Iberian Peninsula covers an approximate surface area of $583254 \mathrm{~km}^{2}$, and it displays an extensive river system with 12 main hydrographic basins.

More than 150 scientific articles and 15 books were reviewed to evaluate the current state of knowledge about crayfishes and their ecological role in the Iberian Peninsula. This literature search was completed using the ISI Web of Knowledge academic database and Google Scholar search engine. Library resources and printed publications available at the Library of Sciences of the University of Navarra were also employed.

To analyse Iberian and global crayfish stocks and production, the official database and fishery statistics of the Food and Agriculture Organization of the United Nations (FAO, 2012) were consulted. This database includes the volume of aquatic species caught by country or area, by species, by major FAO fishing areas and by year for all types of fishing, i.e., commercial, industrial, recreational and subsistence. It also includes aquaculture production and the breeding of other types of fish.

Finally, to analyse the existing legislation related to crayfish in the Iberian Peninsula, the following sources were consulted: 1) the "Boletín Oficial del Estado" (BOE) (Official Bulletin of the State), to check whether any of the crayfish species are included in the Spanish Catalogue of Endangered Species or in the Spanish Catalogue of Invasive Alien Species; 2) "El 
Diário da República Portuguesa" (Diary of the Portuguese Republic); and 3) the Bulletins of the regional Spanish administrations were checked to obtain information on fishing regulations and the conservation status of crayfish species in the Iberian Peninsula. The Official Bulletins of Andalucía, Aragón, Asturias, Cantabria, Castilla-La Mancha, Castilla y León, Cataluña, Extremadura, Galicia, La Rioja, Madrid, Murcia, Navarra and the Comunidad Valenciana were consulted for this purpose. In the País Vasco, where each province exhibit different legislations, the Official Bulletins of Álava, Vizcaya and Guipúzcoa were analysed separately.

\section{RESULTS}

\section{Crayfish species in the Iberian Peninsula}

Of the three families of crayfish that exist in the world (Parastacidae, Cambaridae and Astacidae), only the Astacidae family is native to Europe (Souty-Grosset et al., 2006). The four crayfish species that live in the Iberian Peninsula are described below.

\section{Austropotamobius italicus italicus}

(Faxon, 1914)

The white-clawed crayfish, Austropotamobius italicus italicus, is endemic to freshwater ecosystems in southwestern Europe (Alonso, 2011). Its populations have been substantially reduced during recent decades, mainly because of the crayfish plague and other factors such as pollution or habitat alteration (Alonso et al., 2000). However, this trend has changed because the number of populations has been growing in the last few years (Alonso, 2012). Prior to this decline, A. i. italicus was widely distributed throughout peninsular freshwater habitats, except in the more western areas, the highest mountain ranges and the sub-desert areas of the southeast and Ebro River valley (Matallanas et al., 2011). This species inhabits rivers, streams and reservoirs with clean and well-oxygenated waters and represents the main food source for many bird, fish and mammal species, thus playing a key role in aquatic ecosystems (Zaccara et al., 2004).

The phylogeny, taxonomy, biogeography and origin of $A$. $i$. italicus have been discussed at length in recent years (Grandjean et al., 2002). The purpose of this section is to explain the various scientific studies related to this complex topic. Based on traditional taxonomic analyses, scientists temporarily defined a group of species and subspecies of this crayfish as a specific complex, designated Austropotamobius pallipes s.l. (Chiesa et al., 2011). Mitochondrial 16S rRNA analysis and morphological studies show that A. pallipes s.l. can be divided into two different species: 1) A. pallipes, which is present in France, Switzerland, Germany and the British Isles, and 2) A. italicus, which is found in Spain, France, Italy, south of the Alps and the Balkans (Grandjean et al., 2000; 2002; Zaccara et al., 2004; Fratini et al., 2005; Schulz \& Grandjean, 2005; Trontelj et al., 2005). The distribution range of the Iberian white-clawed crayfish differs if we consider this specific complex to be separated into one or two species. Figure 1a shows the global distribution of A. italicus and A. pallipes (Grandjean et al., 2002; Trontelj et al., 2005; Alonso, 2011). In addition, A. italicus exhibits a high intraspecific genetic oscillation, separating it into three (Grandjean et al., 2002) or four (Fratini et al., 2005) subspecies, with $A$. italicus italicus being the subspecies found in the Iberian Peninsula (Grandjean et al., 2002; Fratini et al., 2005). This subspecies is distributed in Italy, southern Switzerland and Spain (Fratini et al., 2005). In contrast, figure $1 \mathrm{~b}$ shows the global distribution of $A$. pallipes when it is considered as a single species in Europe (Souty-Grosset et al., 2006; Chiesa et al., 2011). A. pallipes and A. italicus present significant differences in their $16 \mathrm{~S}$ rRNA mitochondrial genes. Grandjean et al. (2002) observed a difference of 3.6-5.4\% between the two species, and a difference of $3.5 \%$ was detected by Ghia et al. (2006). DiéguezUribeondo et al. (2008) and Trontelj et al. (2005) observed mitochondrial DNA variations of 11.3 $\%$ and $7.0 \%$, respectively. It is estimated that $2.75 \%$ variation in the $16 \mathrm{~S}$ rRNA mitochondrial gene sequence indicates isolation of one 

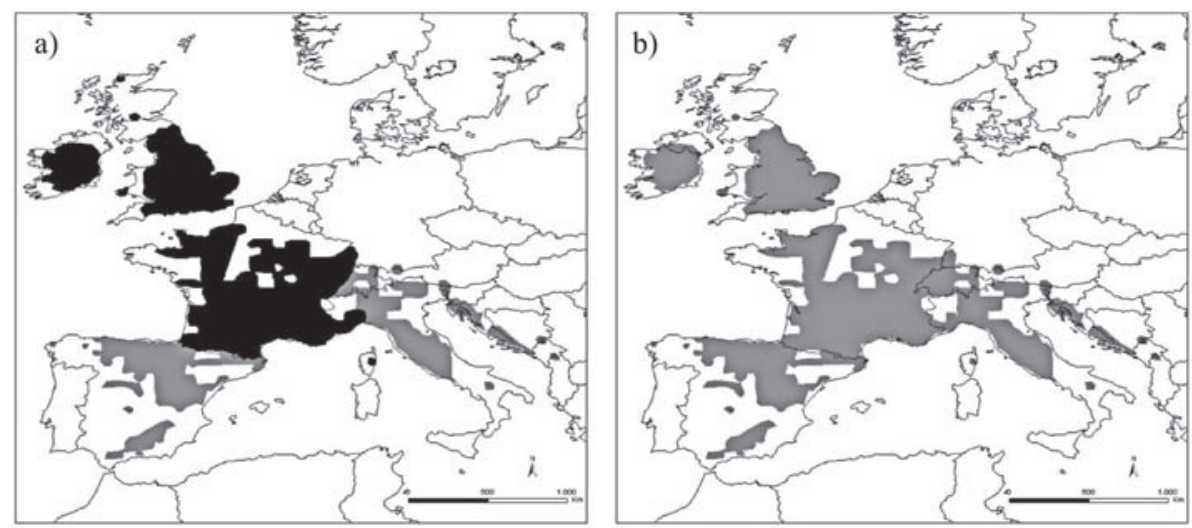

Figure 1. a) Distribution range of the genus Austropotamobius in Europe according to Grandjean et al. (2002). Black colour indicates the Austropotamobius pallipes distribution range, and grey colour represents the Austropotamobius italicus distribution range. b) The Austropotamobius pallipes distribution range in Europe according to Souty-Grosset et al. (2006). a) Distribución del género Austropotamobius en Europa de acuerdo con Grandjean et al. (2002). El color negro indica el rango de distribución de Austropotamobius pallipes y el color gris representa el rango de distribución de Austropotamobius italicus. b) Rango de distribución de Austropotamobius pallipes en Europa de acuerdo con Souty-Grosset et al. (2006).

million years between species. Therefore, these two species could have been isolated over two million years ago (Grandjean et al., 2002; Schulz \& Grandjean, 2005). Due to its wider acceptance, the taxonomic hypothesis represented in figure 1a will be employed in the present paper.

The origin of the Iberian populations of the white-clawed crayfish (A. i. italicus) has been widely discussed in the scientific community. Some authors believe that the Iberian populations of $A$. $i$. italicus were the result of human translocations coming from northwestern Italy in the $17^{\text {th }}$ century. The first molecular studies based on mitochondrial data found very low genetic diversity within the Iberian populations of A. i. italicus, in addition to shared haplotypes and non-significant differentiation between the Iberian and the Italian subspecies (Grandjean et al., 2000; 2002; Fratini et al., 2005; Trontelj et $a l ., 2005)$. Moreover, the absence of historical sources and fossil records supports this hypothesis, given the importance of this crustacean in other European cultures. The "Relaciones Topográficas de Felipe II" is an exhaustive record of Spanish fisheries and their exploitation that was registered for all the areas under the king's mandate, but no specific mention of the presence of this crayfish were found in this resource (Miguel Clavero, pers. comm.; Campos, 2003). The first mention of crayfish in the Iberian Peninsula was made in the Calatayud (Asso, 1784). In the geographical-statistical-historical Dictionary of Spain written by Madoz (1845-1850), crayfish were cited as a fishery resource in the Ebro basin and in some localities situated in the Duero and Tajo basins (Maldonado et al., 2008). Moreover, none of the main languages spoken in the Iberian Peninsula has a specific vernacular name for crayfishes. They are referred to as "cangrejos de río" (literally "river crabs") in Spanish, with similar translations being found in Basque, Catalan and Galician, or "lagostim" in Portuguese (a generic name for all the species of Astacidea group), most likely related to their similarity with some types of marine shrimps.

Other authors consider A. $i$. italicus to be the only native crayfish species in the Iberian Peninsula (Beroiz et al., 2008; Diéguez-Uribeondo et al., 2008; Pedraza-Lara et al., 2010; Matallanas et al., 2011; 2012; Alonso, 2011). Beroiz et al. (2008) used RAPD-PCR to show that there was higher genetic variability in Spanish populations of the white-clawed crayfish than reported by previous authors, who employed different markers. Mitochondrial analyses also suggest a possible natural origin for this species as a consequence of a complex biogeographic and demographic history and further recent natural 
or human-mediated processes that might have shaped its current genetic structure (PedrazaLara et al., 2010). Genetic analyses of peninsular populations employing nuclear and mitochondrial markers (COI and $16 \mathrm{~S}$ rDNA) have shown similar or even higher genetic diversity compared to that reported in previous studies on other Spanish and European populations (Matallanas et al., 2011; 2012). Eight different mitochondrial DNA haplotypes have been found in this species, and it would be impossible to explain this degree of genetic diversity as having occurred within a few hundreds of years (Matallanas et al., 2011).

The source of the crayfish plague (aphanomycosis) is the water mould Aphanomyces astaci (Schicora, 1906). This mould is included among the 100 worst invasive species in the world (Lowe et al., 2000). This pathogen has decreased the populations of native European crayfish species during the past several decades, especially since the introduction of non-native crayfishes infected with the pathogen. However, other factors such as saprolegniasis, pollution, habitat alteration, climatic drought and overfishing also affect white-clawed crayfish populations (Diéguez-Uribeondo et al., 1997; Alonso et al., 2000; Edgerton et al., 2002).

The A. i. italicus populations found in Spain started to decrease dramatically in 1978 (Diéguez-Uribeondo et al., 1997). According to Alonso et al. (2000), the decline of these crayfish populations was more pronounced in the central and southern areas of the Iberian Peninsula. Between 1990 and 2000, there were an estimated 700 remaining populations of white-clawed crayfish (Alonso et al., 2000). However, this negative trend showed a change at the beginning of this century as a consequence of administrative restoration plans, and a total of 1086 populations were estimated to inhabit this region in 2010 (Alonso, 2011). However, these populations remain fragmented and restricted to small river sections, which are usually isolated from the main stream where pathogen-carrying alien crayfish are present, and their average individual size is decreasing.

It is believed that the introduction of aphanomycosis was spatially and temporally linked to the first introduction of North American crayfishes to Europe (Diéguez-Uribeondo et al., 1997). The first isolation of $A$. astaci obtained from white-clawed crayfish corpses in Spain (Burgos and Álava) came from signal crayfish. Thus, North American crayfish introductions could have been the route through which this disease entered the Iberian Peninsula (Diéguez-Uribeondo et al., 1997).

The American crayfishes, Pacifastacus leniusculus and Procambarus clarkii, serve as vectors of the aphanomycosis pathogen during their whole lifespan (Diéguez-Uribeondo et al., 1997; Edgerton et al., 2002; ISSG, 2011; Longshaw, 2011). However, American crayfishes are resistant to this disease as a result of coevolution between the pathogen and host. As a consequence of this coevolution, the pathogen is restricted exclusively to the cuticle of these crayfishes, except when they experience stress (Diéguez-Uribeondo et al., 1997; Edgerton et al., 2002; Longshaw, 2011).

This pathogen exhibits three different stages: the mycelium, zoospore and cyst stages (Oidtmann et al., 2002). Many zoospores are formed when an infected crayfish is dying or has recently died. These zoospores constitute the dispersion structures of the pathogen. They are able to survive for up to two weeks in the mud, and they are motile in the water for three days at $10^{\circ} \mathrm{C}$ (Edgerton et al., 2002). Nevertheless, it is difficult for this pathogen to survive for a long period of time in a natural environment in the absence of a suitable host. Its spores and mycelium die when exposed to extreme temperatures and desiccation (Oidtmann et al., 2002). Sodium hypochlorite, $\mathrm{MgCl}_{2}$, iodine and malachite green can be used to sterilise and/or reduce sporulation (Edgerton et al., 2002), although Oidtmann et al. (2002) suggested that the best decontamination method is to boil materials at $100{ }^{\circ} \mathrm{C}$ for one minute.

The infection generated by $A$. astaci can be spread easily from one river basin to another through the movements of crayfishes and fishes or when attached to contaminated equipment, such as nets, boots, clothes and other items (e.g., Oidtmann et al., 2002). Although it is difficult to determine whether a crayfish is infected, 
symptoms such as brown melanisation of the exoskeleton or whitening of the tail muscle are sometimes observed (Edgerton et al., 2002). Once the infection has begun, crayfish usually die after one or two weeks (Edgerton et al., 2002).

The protection status of the white-clawed crayfish varies among different entities. This species has been catalogued as endangered in the World Red List (IUCN, 2011) since 2010 (it was previously catalogued as vulnerable). In Europe, it is included in the Annex II - species of community interest, meaning that its conservation requires the designation of Special Areas of Conservation (SAC) - Annex V of the Habitats Directive and Annex III of the Berne Convention. In Spain, A. i. italicus is catalogued as vulnerable in the National Catalogue of Endangered Species, and its protection status differs among different regional administrations.

\section{Procambarus clarkii (Girard, 1852)}

The red swamp crayfish, Procambarus clarkii, is native to the wetlands of the southern United States of America (U.S.A.) and northeastern Mexico (Larson \& Olden, 2011). It is the most invasive crayfish species in the world and is found in Africa, Asia, Europe and North and South America (Lowe et al., 2000; Larson \& Olden, 2011). The features responsible for the high invasive potential of this species are its high fecundity, rapid growth, short life cycle, high aggressiveness and ability to adapt to poor environmental conditions (e.g., low oxygen, salinity, acidity and pollution) and to tolerate sudden changes in water levels (e.g., Geiger et al., 2005). With regard to this last characteristic, it is important to note that $P$. clarkii can withstand long periods of drought by excavating galleries more than $2 \mathrm{~m}$ deep to increase its proximity to the water table, where the humidity is higher (Barbaresi \& Gherardi, 2000; Souty-Grosset et al., 2006). In summary, this invasive species can survive in a wide range of environmental conditions and habitats, such as crop areas, lakes, canals, rivers, marshes and swamps (ISSG, 2011).

The red swamp crayfish is native to Louisiana marshes (U.S.A.), and its first introduction to $\mathrm{Eu}-$ rope occurred in southern Spain. It was introduced for aquaculture production between 1972 and 1974 in the marshes of the Guadalquivir River and quickly established itself in the wild (Barbaresi \& Gherardi, 2000; Geiger et al., 2005; Souty-Grosset et al., 2006; Holdich et al., 2009). Several years later, $P$. clarkii colonised other areas of the Iberian Peninsula, such as the Albufera of Valencia (1978), the Ebro delta, Zamora (1979) and Lugo (Alonso et al., 2000). Human translocations and the sale of live specimens at fish markets supported its expansion (Geiger et al., 2005; Souty-Grosset et al., 2006). P. clarkii is currently the most abundant crayfish species in the Iberian Peninsula (Alonso et al., 2000; SoutyGrosset et al., 2006), showing especially high abundance in the middle and lower stretches of rivers (Alonso et al., 2000; Oscoz et al., 2008). Figure 2 a shows that most of its European populations are found in the Iberian Peninsula.

The ecological characteristics of the red swamp crayfish have triggered a series of negative socio-economic, health and environmental impacts since its introduction to the Iberian Peninsula (Geiger et al., 2005; Larson \& Olden, 2011). Furthermore, its introduction to the lower Guadalquivir has caused a conflict of interests: $P$. clarkii produces high economic losses and is responsible for massive devastation of rice crops, but is also an important source of wealth as a fishing resource (Cano \& Ocete, 1994).

As noted above, rice crops are severely impacted by the red swamp crayfish. These impacts are produced indirectly as a consequence of the abundant galleries that this species digs within the cultivation areas of this crop, thus damaging the water drainage capability of these fields (Barbaresi \& Gherardi, 2000). In addition, the red swamp crayfish feeds on rice, reducing the germination and establishment of rice seedlings (Cano \& Ocete, 1994; Souty-Grosset et al., 2006). It also damages various types of infrastructure, such as water canals, bridges, roads and highways (Cano \& Ocete, 1994).

In 1997, a tularemia outbreak occurred in the province of Cuenca in association with $P$. clarkii handling (Díaz de Tuesta et al., 2001).Francisella tularensis tularensis (McCoy \& Chapin, 1912) is 

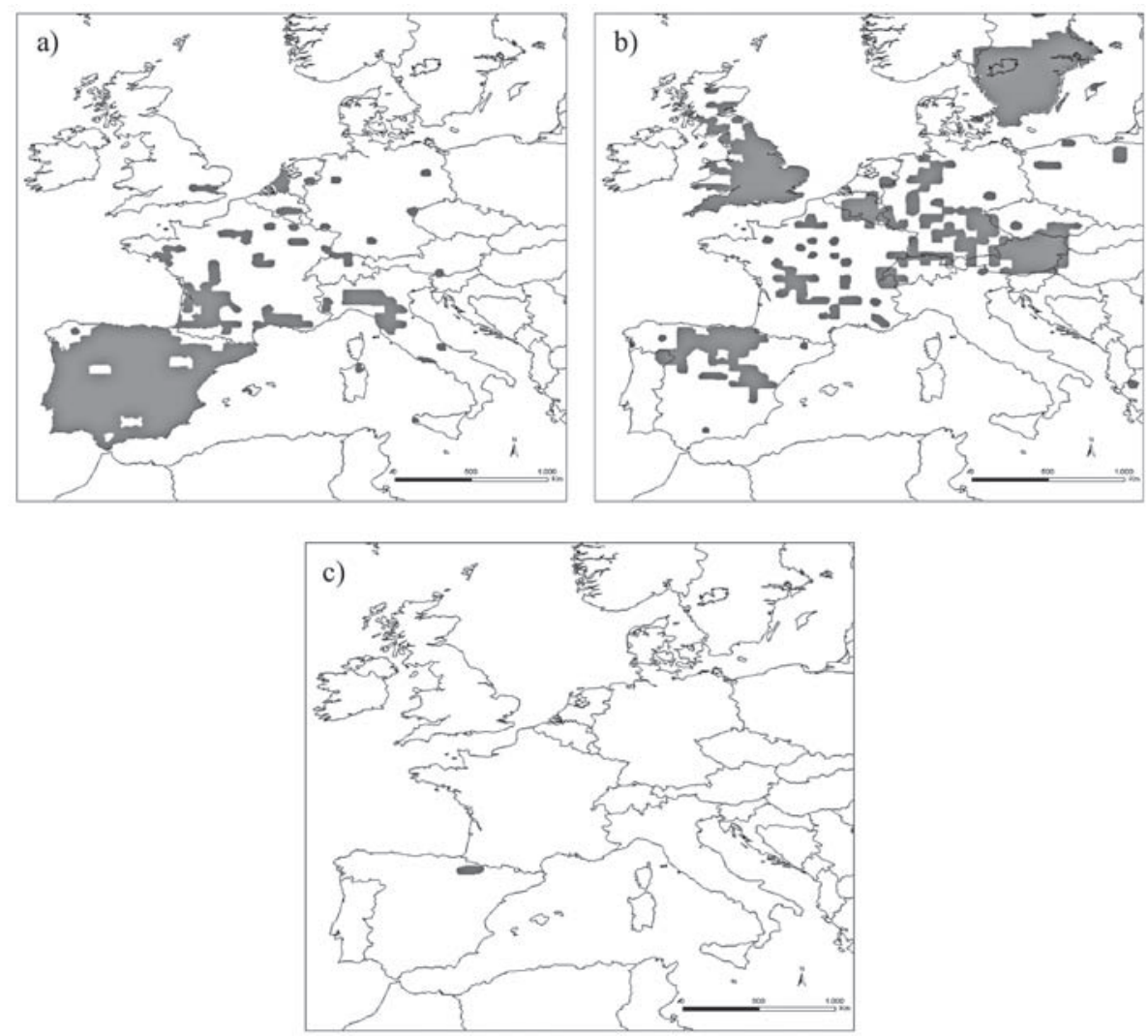

Figure 2. a) Red swamp crayfish, Procambarus clarkii, b) signal crayfish, Pacifastacus leniusculus, and c) Yabbie, Cherax destructor distribution range in Europe. The signal crayfish distribution range in Norway, Slovakia, Croatia, Estonia and Denmark is not represented on the map; (c) Scientific publications MNHN, Paris, 2006 (modified from Holdich et al. 2009 for Procambarus clarkii and Pacifastacus leniusculus and from Souty-Grosset et al. 2006 for C. destructor). a) Distribución del cangrejo rojo de las marismas Procambarus clarkii, b) cangrejo señal Pacifastacus leniusculus y c) Yabbie Cherax destructor en Europa. Para Pacifastacus leniusculus la distribución en Noruega, Eslovaquia, Croacia, Estonia y Dinamarca no está representada en el mapa (C)Publicaciones científicas MNHN, Paris, 2006 (modificado de Holdich et al. 2009 para Procambarus clarkii y Pacifastacus leniusculus y de SoutyGrosset et al. 2006 para C. destructor).

the bacterium that causes this serious infectious disease. This bacterium has been found in the stomach, hepatopancreas and water of P. clarkii, but not in its exoskeleton. These findings indicate that the red swamp crayfish is not a direct transmission vector of tularemia, and the most likely cause of this outbreak was the contamination of river water with animals killed by tularemia (lagomorphs), which then also infected P. clarkii.

Furthermore, this non-native species generates negative environmental impacts on macrophytic algae, amphibians, molluscs and macroinvertebrate diversity in aquatic ecosystems (Rodríguez et al., 2005; Souty-Grosset et al., 2006; Correia et al., 2005; 2007). Some authors suggest that the red swamp crayfish increases water turbidity, hence reducing light penetration and macrophytic algae productivity (Geiger et al., 2005; Larson \& Olden, 2011; Marchi et al., 2011). It also modifies biogeochemical cycles and unbalances the food chain, decreasing the complexity of ecosystems (Marchi et al., 2011).

\section{Pacifastacus leniusculus (Dana, 1852)}

The signal crayfish, Pacifastacus leniusculus, is endemic to the northwestern U.S.A. and southwestern Canada and inhabits a wide range of habitats, from small streams to large rivers and lakes. This species is found in 24 European coun- 
tries and is the most widespread alien species in Europe (Souty-Grosset et al., 2006; Holdich et al., 2009; Johnsen \& Taugbø1, 2010) (Fig. 2b). The signal crayfish is better adapted than the red swamp crayfish to upstream stretches. This crustacean exhibits higher rates of growth and sexual maturation than the white-clawed crayfish, but lower rates than the red swamp crayfish. Its ecological characteristics include tolerance of salty water, a wide temperature range, resistance to $\mathrm{pH}$ levels above six and a high capacity for enduring long periods out of water (Souty-Grosset et al., 2006).

The signal crayfish was introduced to Spain between 1974 and 1975 at two crayfish hatcheries, which were located in the Cifuentes River (Guadalajara) and Ucero River (Soria), respectively, with the introduced individuals coming from Simmontorp, a Swedish crayfish hatchery (Alonso et al., 2000). In later years, new signal crayfish introductions were carried out, but with the individuals involved coming directly from North America. The restocking programs of some administrations, such as Navarra, País Vasco and Castilla y León, facilitated its expansion (Alonso et al., 2000). By 2004, it was present in Orense, Castilla y León, Cantabria, País Vasco, Navarra, Teruel, Lleida, Castellón, Comunidad Valenciana, Cuenca, Guadalajara, Albacete, Madrid and Granada. The first reference to signal crayfish populations in southern Spain in the literature comes from 2000, in the Riofrio River (Loja, Granada) (Dana et al., 2010), though its presence in other southern locations has been reported as well. While the distribution range of signal crayfish in the Iberian Peninsula is not currently as wide as the distribution of the red swamp crayfish (Fig. 2b), its populations are undergoing expansion in the central peninsula as a result of illegal translocations. The fishing legislations related to this species have been changing. The initial mode of management was fishing area limitations, whereas free fishing is currently allowed (Annex 1, www. limnetica.net/internet).

As mentioned previously, some regional administrations conducted a signal crayfish introduction program in the 1980 s with the aim of creating a "green barrier" between the red swamp crayfish and the white-clawed crayfish (Cuéllar \& Cuéllar, 2000). The signal crayfish was thought to represent the perfect "ecological counterpart" of the white-clawed crayfish and to be resistant to aphanomycosis. Nevertheless, there is no scientific evidence supporting the actual creation of this "green barrier", as both species, $P$. clarkii and $P$. leniusculus, have been observed to coexist within the same stretch of river without any appreciable difficulties (Oscoz et al., 2008; Larson \& Olden, 2011). In fact, Alonso \& Martínez (2006) studied shelter competition between red swamp crayfish and signal crayfish under laboratory conditions, and in most experiments, the red swamp crayfish was both the first species to be observed in a shelter $(70.8 \%)$ and the long-term winner $(62.5 \%)$.

Additionally, P. leniusculus also carries the pathogen responsible for crayfish plague in its cuticle. The introduction of these non-native crayfish species has further complicated the situation because they were introduced together with branchiobdellidan species. The branchiobdellidans, or crayfish worms, are obligate ectosymbionts related to both oligochaetes and hirudinids (Souty-Grosset et al., 2006). There are seven endemic European species of Branchiobdellidae belonging to the genus Branchiobdella. In some river stretches, signal crayfish are infected by a non-indigenous species of Branchiobdellidae, Xironogiton victoriensis (Gelder \& Hall, 1990) (Oscoz et al., 2010). This species causes a negative impact among fishermen who reject "infected" individuals for consumption.

The signal crayfish also produces negative effects in macrophytes, macroinvertebrates, snakes, benthic fishes and amphibian larvae (Johnsen \& Taugbøl, 2010).

\section{Cherax destructor (Clark, 1936)}

The Yabbie, Cherax destructor is native to eastern Australia and is found in New South Wales, Victoria and South Australia (Souty-Grosset et al., 2006). This crustacean inhabits marshes, streams, rivers and reservoirs with sandy and muddy bottoms where the water exhibits a moderate turbidity level, thus offering better 
protection from predators such as fish and birds (Withnall, 2000). The Yabbie can withstand temperatures between $1{ }^{\circ} \mathrm{C}$ and $35^{\circ} \mathrm{C}$, with its optimum range for growth falling between $20^{\circ} \mathrm{C}$ and $30^{\circ} \mathrm{C}$. When the water temperature drops below $16^{\circ} \mathrm{C}$, its metabolism decreases to a level corresponding to partial hibernation (Withnall, 2000).

The first introduction of $C$. destructor into Spain and Europe took place in Girona (Catalonia) in 1983, involving specimens from California (Souty-Grosset et al., 2006). Subsequently (1984-1985), another introduction was conducted in the province of Zaragoza, where a population was eventually stabilised in Gordués, near Sos del Rey Católico (Holdich et al., 2009). Because $C$. destructor is sensitive to aphanomycosis, some of its populations have been eradicated using the crayfish plague pathogen. However, some populations persist to the present day (Holdich et al., 2009). It is believed that there are at least four stable populations in Spain: one in Aragon and three in Navarra (Souty-Grosset et al., 2006) (Fig. 2c). Moreover, this species has been detected in other European countries in recent years. For example, a population was detected in Italy in 2008, and one individual was reported in Lake Geneva, Switzerland (Scalici et al., 2009).

The Yabbie is commercially produced in some regions of Australia (New South Wales, Victoria and South Australia), and it is considered a delicacy and sold live in North America, Switzerland, Germany and England (Souty-Grosset et al., 2006).

This species displays highly aggressive, competitive and predatory behaviour. Similar to the American crayfishes (P. clarkii and P. leniusculus $), C$. destructor is able to dig a network of tunnels with depths of $0.5 \mathrm{~m}$ to $2 \mathrm{~m}$ to survive dry summer periods (Withnall, 2000). These galleries damage crops, lawns, dams and irrigation canals (Gherardi, 2007).

The Yabbie is considered a serious threat to native Cherax tenuimanus populations in western Australia because of its high reproductive potential and high tolerance to various environmental conditions. For these reasons, this invasive species is considered a serious threat to European aquatic ecosystems (Souty-Grosset et al., 2006).

\section{Impacts and management of crayfishes}

The introduction of non-native crayfishes to freshwater ecosystems has provided an important food resource for species at higher trophic levels, such as fish, birds and mammals (Geiger et al., 2005). Energy from detritus is transferred directly to higher trophic levels, thereby reducing the number of trophic levels. Consequently, a decline in the importance of macrophyte algae, herbivores and primary carnivores takes place, altering the overall structure and function of aquatic food chains (Rodríguez et al., 2005; Geiger et al., 2005).

The red swamp crayfish exhibits more herbivorous habits than the white-clawed crayfish, thus producing significant changes in aquatic ecosystems (Rodríguez et al., 2005). For example, following the introduction of the red swamp crayfish into Lake Chozas (León), a decline in the populations of herbivorous birds (e.g., ducks, coots) was observed due to a reduction of food and nesting habitats (Rodríguez et al., 2005).

Furthermore, there are studies showing that non-native crayfishes have threatened and even eradicated amphibian species in many rivers and lakes in the Iberian Peninsula (Ilhéu et al., 2007). For example, Rodríguez et al. (2005) found that four frog species disappeared after the introduction of P. clarkii.

Nevertheless, the presence of non-native crayfishes has a positive impact in some cases on certain fish-eating species, such as the otter Lutra lutra L., the bittern Botarus stellaris L., the little egret, Egretta garzetta L., and the heron Ardea purpurea L. (Barbaresi \& Gherardi, 2000; Correia et al., 2005; Geiger et al., 2005; Rodríguez et al., 2005).

Eradication methods could become an alternative means of eliminating non-native crayfishes, although such methods are not always effective (Peay \& Hiley, 2001). For example, applying heavy fishing pressure could appear to be a good control mechanism for these populations a priori, although this increased pressure may have negative effects because fishermen often act as dispersal agents (Alonso et al., 2000). A total of 25492 signal crayfishes were eliminated from the Riofrío (Loja, Granada) 
between 2005 and 2008, as shown by the "Plan Andaluz para el Control de las Especies Exóticas Invasoras". In eliminating these crayfishes, workers used a combination of methods, such as minnow traps, electrofishing, hand catching and artificial shelters. Thus, the size of the signal crayfish population and the risk of its dispersion were dramatically minimised, as the population was brought near or below the minimum size for reproduction. However, other studies have suggested that manual removal has not effective been at any level of effort (e.g., Peay $\&$ Hiley, 2001). To control non-native crayfish populations, management decisions should be focused on controlling the main factor involved in their expansion, which is human translocations. Nevertheless, other effective methods can be applied. Corkum (2004) and Stebbing et al. (2003) have suggested that capturing signal crayfish using pheromones could become a widely applied eradication method in the future because pheromones also act as repellents for local crayfish populations (Johnsen \& Taugbøl, 2010). The possibility of isolating and developing a biological control agent specifically to influence invasive species should be considered (Freeman et al., 2007). Additionally, the construction of dams has proven to be effective in restraining the expansion of $P$. clarkii to headwaters, thereby preventing new aphanomycosis infections in white-clawed crayfish populations (Dana et al., 2011). Peay \& Hiley (2001) considered manual removal, habitat destruction, barriers, predators, diseases, pheromones and biocides for the eradi- cation of signal crayfish populations in the UK. They concluded that the eradication or control of a signal crayfish population is only likely to be achieved through chemical control (biocides). Peay et al. (2006) studied a new methodology based on the use of natural pyrethrum for eradicating signal crayfish in ponds.

For the eradication of $C$. destructor, Scalici et al. (2009) proposed that direct pathogen application or the introduction of infected crayfish should be implemented. However, these methods may represent a high risk to the local populations of $A$. $i$. italicus, which is also susceptible to the disease (Oscoz et al., 2010). Thus, following this procedure to eradicate $C$. destructor would only be carried out in areas where no evidence of the white-clawed crayfish species is found. Although low water temperatures constitute natural barriers to the spread of this species, there is no way to prevent human translocations, which are the main means of the spreading of all crayfish species (Scalici et al., 2009).

\section{Global and Spanish crayfish production}

According to FAO statistics, the red swamp crayfish has been the species with the highest global production since the 1970s (ISSG, 2011; FAO, 2012). The global production of $A$. i. italicus and A. pallipes during the 1950s, 1960s and 1970s was also remarkable, considering that their range was limited to a small region in Europe (Fig. 1). For example, an average of $1380 t$ of $A$. i. italicus and A. pallipes was produced annually during

Table 1. Evolution of the average annual production of crayfish species present in the Iberian Peninsula by country (tonnes, $t$ ) (FAO 2012). Evolución de la producción promedio anual por países (toneladas, t) de las especies de cangrejo de río presentes en la Península Ibérica (FAO 2012).

\begin{tabular}{|c|c|c|c|c|c|c|c|c|}
\hline Country & Species & $50-59$ & $60-69$ & $70-79$ & $80-89$ & $90-99$ & 00-09 & 2010 \\
\hline Kenya & P. clarkii & & & & 49 & 33 & 17 & 20 \\
\hline U.S.A. & P. clarkii & 16 & 242 & 3775 & 28663 & 24438 & 33995 & 52942 \\
\hline China & P. clarkii & & & & & & 139726 & 563281 \\
\hline Indonesia & C. destructor & & & & & & 2 & 8 \\
\hline Spain \& Italy & P. clarkii & & & 59 & 2533 & 2263 & 200 & 1509 \\
\hline \multirow[t]{2}{*}{ Finland } & P. leniusculus & & & & 1.7 & 5.8 & 137 & 226 \\
\hline & A. italicus & 1380 & 440 & 679 & 37 & & & \\
\hline Australia & C. destructor & & & & 5 & 185 & 143 & 51 \\
\hline
\end{tabular}


the $1950 \mathrm{~s}$, compared to $16 t$ of $P$. clarkii. However, this pattern was dramatically reversed a few years later, when the production of $A$. i. italicus and $A$. pallipes decreased dramatically, mainly in response to aphanomycosis disease. In contrast, the production of $P$. clarkii increased exponentially, reaching annual global production of 173 938t (Table 1). In contrast to the red swamp crayfish, there has historically been little or no global production of $P$. leniusculus and $C$. destructor, although there has been an increasing trend in the last three decades.

European crayfish production is lower than Asian or American production. Nevertheless, the crayfish market has been very important to the economy of some Spanish regions (Cano \& Ocete, 1994; Souty-Grosset et al., 2006) (Table 1). Until 2002, almost all production data for P. clarkii came from America (U.S.A.) and, to a lesser extent, from Europe. However, the FAO started recording production statistics in Asia (China) in 2003, and the global production data were multiplied six times (Table 1).

There is no other place in America where the red swamp crayfish has as great an impact on the economy as it has in the southern states. This species is produced and consumed as food in several areas. The state of Louisiana dominates both aquaculture and wild capture fisheries of this crayfish, which contribute over 150 million dollars annually to the state economy. In Louisiana, approximately 48000 ha are used to cultivate this crustacean, representing 90-95 \% of U.S. production (McAlain \& Romaire, 2007). Nevertheless, China is the largest crayfish producer in the world, with a 2010 total production that was ten times higher than that of the U.S.A. (Table 1).

Figure 3 shows a chronology of the annual production of the white-clawed crayfish and red swamp crayfish in Spain in tonnes $(t)$. Since data have been available (starting in 1980), A. i. italicus has shown an annual production of between $500 t$ and 3000t. However, the production of the signal crayfish was only one tonne per year between 1998 and 2002. The first production data for the red swamp crayfish in Spain were obtained in 1977, indicating an annual produc-

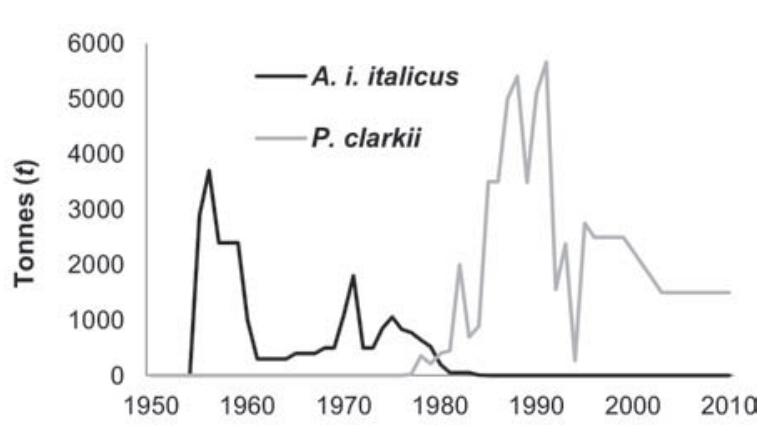

Figure 3. Evolution of the annual production (tonnes, $t$ ) of $A$. $i$. italicus and $P$. clarkii in the Iberian Peninsula between the years 1950 and 2010 (FAO 2012). Evolución de la producción anual (toneladas, t) de A. i. italicus y P. clarkii en la Península Ibérica entre los años 1950 y 2010 (FAO 2012).

tion of $22 t$. Subsequently, the annual production of this species increased to $400 t$ in 1980 and $5662 t$ in 1991 (Fig. 3). In recent years, red swamp crayfish production has been estimated to be $1500 t$ per year, although this is most likely an underestimation.

The Ministry of Agriculture, Fisheries and Food (2007) reported an index of commercialisation for the red swamp crayfish of 2 or $3 t$ /year in $\mathrm{El}$ Palmar (Valencia) and more than $6 t$ /year in Catalonia between 2005 and 2006. Additionally, the region of Castilla y León produces a total of $3 \cdot 10^{5}$ crayfish per year, with a value of 57660 Euros.

\section{Legislation and commercialisation}

The legislation addressing white-clawed crayfish conservation is complex because it includes regulations related to conservation, national- and regional-scale commercialisation and fishing regulations at the provincial level. While many of the regional administrations have developed their own laws for fishing and conservation, the marketing of this species is still nationally regulated. Limitation in live crayfish commercialisation is important for the control of non-native crayfish populations. Although the sale of red swamp crayfish is allowed in Spain, the commercialisation of signal crayfish is not permitted by national legislation. This prohibition could explain the different patterns of dispersion observed for the two species. 


\section{Management and conservation}

Table 2 shows the global, Spanish and Portuguese cataloguing of crayfish species that inhabit the Iberian Peninsula. Furthermore, it includes the most important features of each species. Annex 1 (supplementary material: www.limnetica.net/internet) summarises the principal laws for these species included in the local and national legislation of Spain and Portugal.

\section{Fishing regulations}

All the information concerning authorisations regarding fish sizes, numbers of catches and fishing periods for the red swamp crayfish and signal crayfish is provided within the same Annex.

\section{DISCUSSION}

The origin of Iberian A. i. italicus populations has been a topic of debate in recent years. First, it is essential to clarify whether A. $i$. italicus is an introduced species or the only native species of crayfish in the Iberian Peninsula, as crayfish management policies should be completely different depending on the answer to this question. Some authors believe that the Iberian populations of this species are the result of human translocations from Italy because mitochondrial data have shown very low genetic diversity between
Iberian and Italian populations (Grandjean et al., 2002; Fratini et al., 2005; Trontelj et al., 2005). In addition, certain authors believe that there are no fossils or historical references available to help track the biogeographic evolution of this species (Madoz, 1845-1850). Nevertheless, there are many reviews that criticise these studies due to the small number of samples used (eight populations and only one individual for each one). According to Chiesa et al. (2011), the mitochondrial gene sequencing method used by most authors to study the phylogeny of the Austropotamobius genus is not reliable, and they argue that this technique only provides a partial view because it solely reflects the maternal phylogeny. Furthermore, these studies did not consider the major reduction of population sizes and subsequent human translocations of Iberian A. i. italicus, which could also reduce their genetic diversity, causing a bottleneck (Diéguez-Uribeondo et al., 2008; Pedraza-Lara et al., 2010). In addition, new references to the white-clawed crayfish in the Iberian Peninsula have been found in medieval and Arabic texts (Diéguez-Uribeondo et al., 2008). The question of vernacular names complicates the situation but does not prove that the white-clawed crayfish is introduced. Other recent studies have shown that this species could be native to the Iberian Peninsula because the genetics of its peninsular populations differ sufficiently from its Italian populations to infer that their differentiation occurred more than a few hundreds

Table 2. Summary of crayfish species present in the Iberian Peninsula and catalogued in the world (IUCN), Spain (Real Ordinance 139/2011 and 1628/2011) and Portugal (Ordinance-Law n ${ }^{\circ}$ 49/2005 and Ordinance-Law 565/99). LC: least concern; VU: vulnerable; EN: endangered; S: south; NE: northeast; NW: northwest; E: east. Tabla resumen de las especies de cangrejo de río presentes en la Península Ibérica y su catalogación mundial (IUCN), española (Real Decreto 139/2011 y 1628/2011) y portuguesa (Decreto-Ley $n^{o}$ 49/2005 y Decreto-Ley 565/99). LC: preocupación menor; VU: vulnerable; EN: en peligro; S: sur; NE: noreste; NW: noroeste; E: este.

\begin{tabular}{lcccc}
\hline & A. . italicus & P. clarkii & P. leniusculus & C. destructor \\
\hline Origin & SW Europe & S U.S.A., NE Mexico & NW U.S.A. and SW Canada & E Australia \\
Family & Astacidae & Cambaridae & Astacidae & Parastacidae \\
Year of introduction & - & $1973-1974$ & $1974-1975$ & $1984-1985$ \\
Aphanomycosis & Sensitive & Resistant (carrier) & Resistant (carrier) & Sensitive \\
Global legislation & EN & LC & LC & VU \\
Spanish legislation & VU & Invasive & Exotic & Invasive \\
Portuguese legislation & Community interest & Invasive & - \\
\hline
\end{tabular}


of years ago (Beroiz et al., 2008; Pedraza-Lara et al., 2010; Matallanas et al., 2011; 2012). Thus, these authors suggest that there are no strong arguments calling into question the indigenous status of the white-clawed crayfish.

There is a long-standing consensus suggesting that the main cause for the decline of $A$. $i$. italicus populations has been the Aphanomyces astaci water mould. The life cycle and dispersal mechanisms of Aphanomyces astaci are well known, and it is considered to be a pathogen that requires a host to survive. Thus, it is important to implement management measures to account for the fact that non-native crayfishes, specifically Procambarus clarkii and Pacifastacus leniusculus, are carriers of the crayfish plague. However, C. destructor and A. i. italicus are sensitive to crayfish plague.

The protection status of the white-clawed crayfish differs among the different regional administrations of Spain. A. i. italicus is catalogued as "endangered" in nine regional administrations and "vulnerable" in six regional administrations. In addition, five regional administrations have a recovery plan for this species. To reduce these efforts and considering Spain together with Portugal as an ecological unit, it seems logical to develop a single recovery plan for the species and make the regional administrations responsible for implementing and applying adequate measures.

Many data suggest that the introduction of the red swamp and signal crayfishes between 1972 and 1975 was directly related to the beginning of the crayfish plague because white-clawed crayfish populations began to decline sharply after 1978 (Diéguez-Uribeondo et al., 1997). This is a clear example of how the introduction of nonnative species negatively affects the environment. Some regional administrations have carried out signal crayfish restocking under the following two hypothetical goals: 1) to create a "green barrier" between the red swamp crayfish and the native crayfish and 2) to introduce an "ecological substitute" for the white-clawed crayfish. Nevertheless, the signal crayfish does not prevent the passage of the red swamp crayfish, and it carries the pathogenic crayfish plague agent. The current aim is to find a way to eradicate these non-native populations by procuring a potential habitat where A. i. italicus could be reintroduced and recovered. Some possible eradication methods are mentioned in the management section.

The negative impacts caused by signal crayfish in freshwater ecosystems are well known (Dunn et al., 2009; Johnsen \& Taugbøl, 2010). However, this species has been subjected to incorrect management policies for several years, focused on its utilisation and the conservation of its populations as an exploitable resource. It seems logical that all non-native Iberian crayfish species, i.e., Procambarus clarkii, Cherax destructor and Pacifastacus leniusculus, should be addressed using the same management policies, directing all efforts towards their eradication.

The current knowledge of Iberian $C$. destructor crayfish populations seems to be sparse. Considering the aggressive, competitive and predatory behaviour of this species, its presence and spreading could have negative effects in the future. Thus, the implementation of measures to prevent its spread is urgently required, despite the fact that its populations are currently very restricted.

The data on Spanish crayfish production were obtained from an official source (FAO), whose accuracy is not high. These data were collected from the Agriculture Minister through annual direct polling of responsible managers in each province and it is known that some provinces have provided data without conducting any control of recreational fishing in the past. For this reason, subsequent interpretation of these data must be conducted with caution.

\section{Legislation: conservation and fisheries}

Analysis of the existing legislation related to the conservation and management of Iberian crayfish species yields ambiguous results. The Spanish Catalogue of Invasive Alien Species (Boletín Oficial del Estado, 2011), as described in its transitional provision, includes all of the introduced crayfish species in the Iberian Peninsula prior to the implementation of Law 42/2007 addressing hunting, fishing and forestry. Under this provision, "in order to prevent these invasive species from spreading beyond their current range, hunting, fishing and forestry 
strategies are proposed as management, control and eradication measures".

This provision also states that if hunting, fishing and forestry activities involving one of the species cited therein are promoting its expansion and establishment outside its current range, the General Directorate of the Environment and Forestry Policies must take appropriate steps to manage this species.

There is a large body of literature suggesting that non-native crayfish species have a negative impact on freshwater ecosystems (Geiger et al., 2005; Rodríguez et al., 2005; Souty-Grosset et al., 2006; Ilhéu et al., 2007). Therefore, a primary management objective should be to eradicate introduced species and prevent the establishment of new invasive ones. It must be kept in mind that once a new species is established in the wild, eradication becomes very challenging because of the complexity of ecosystems and the difficulty of finding a method that only affects the target species. Thus, it appears that is quite difficult to eradicate P. clarkii and P. leniusculus populations, though it is easier to prevent new introductions of non-native species. Some authors suggest that the best way to avoid human translocations is through fishing prohibition to avoid generating expectations related to fishing. At present, there are few populations of $C$. destructor, and it is very important to prevent the expansion of this species.

Fishing regulations for the signal crayfish have been changing during recent years in a manner that differs between the Spanish regional administrations. For several years, the fishing regulations published by regional administrations established limitations such as quotas and sizes to regulate and preserve the populations of signal crayfish. However, the recent policies of most regional administrations allow fishing of signal crayfish, without any type of restriction. On the other hand, in the regional administrations of Andalucía, Castilla-La Mancha, Comunidad Valenciana, Extremadura, Guipúzcoa and Murcia, signal crayfish fishing is forbidden (Annex 1).

In conclusion, to properly manage crayfish populations in the Iberian Peninsula, we propose the following actions: 1) eradication of non-native crayfish populations, 2) strictly monitoring watercourses to prevent invasion by these or other species of alien crayfishes and 3) informing and warning the human population, especially fishermen, about the serious effects that the introduction of non-native crayfishes causes in the environment.

\section{ACKNOWLEDGEMENTS}

We appreciate the improvements in English usage made by Ibon Tobes. A preliminary draft of this paper was revised by Enrique Baquero, Jordi Puig and Carolina Santamaría. Iván Vedia benefitted from a predoctoral grant from the Asociación de Amigos-University of Navarra (2011-2012).

\section{REFERENCES}

ALONSO, F., C. TEMIÑO \& J. DIÉGUEZ-URIBEONDO. 2000. Status of the white-clawed crayfish, Austropotamobius pallipes (Lereboullet, 1858), in Spain: distribution and legislation. Bulletin Français de la Pêche et de la Pisciculture, 356: 31-53.

ALONSO, F. \& R. MARTÍNEZ. 2006. Shelter competition between two invasive crayfish species: a laboratory study. Bulletin Français de la Pêche et de la Pisciculture, 380-381: 1121-1132.

ALONSO, F. 2011. Austropotamobius italicus (Faxon, 1914). In: Atlas y Libro Rojo de los Invertebrados amenazados de España (Especies Vulnerables). J. R. Verdú, C. Numa, E. Galante (eds.): 651-672. Dirección General de Medio Natural y Política Forestal, Ministerio de Medio Ambiente, Medio rural y Marino, Madrid, Spain.

ASSO, I. J. 1784. Introductio in Oryctographiam et Zoologiam Aragoniae. Accedit. Enumeratio Stirpium in eadem Regione noviter detectarum. Facsimile edition, Amsterdam, Netherlands.

BARBARESI, S. \& F. GHERARDI. 2000. The invasion of the alien crayfish Procambarus clarkii in Europe, with particular reference to Italy. Biological Invasions, 2: 259-264.

BEROIZ, B., C. CALLEJAS, F. ALONSO \& M. D. OCHANDO. 2008. Genetic structure of Spanish white-clawed crayfish (Austropotamobius pallipes) populations as determined by RAPD analysis: 
reasons for optimism. Aquatic Conservation: Marine and Freshwater Ecosystems, 18: 190-201. BOLETÍN OFICIAL DEL ESTADO. 2011. Real Ordinance 1628/2011, de 14 de noviembre, por el que se regula el listado y catálogo español de especies exóticas invasoras. Madrid, España BOE 298: 132711-132735.

CAMPOS, F. J. 2003. Las Relaciones Topográficas de Felipe II: Índices, fuentes y bibliografía. Anuario jurídico y económico escurialense, 36: 439-574.

CANO, E. \& M. E. OCETE. 1994. Estimación sobre las repercusiones socio-económicas de Procambarus clarkii Girard (Decapoda, Cambaridae) en las marismas del Bajo Guadalquivir. Boletín Sanidad Vegetal Plagas, 20 (3): 653-660.

CHIESA, S., M. SCALICI, R. NEGRINI, G. GIBERTINI \& F. NONNIS MARZANO. 2011. Finescale genetic structure, phylogeny and systematics of threatened crayfish species complex. Molecular phylogenetics and evolution, 61 (1): 1-11.

CORKUM, L. D. 2004. Pheromone signalling in conservation. Aquatic Conservation: Marine and Freshwater Ecosystems, 14 (4): 327-331.

CORREIA, A. M., N. BANDEIRA \& P. M. ANASTÁCIO. 2005. Predator-prey interactions of Procambarus clarkii with aquatic macroinvertebrates in single and multiple prey systems. Acta Oecologica, 28 (3): 337-343.

CORREIA, A. M. \& P. M. ANASTÁCIO. 2007. Shifts in aquatic macroinvertebrate biodiversity associated with the presence and size of an alien crayfish. Ecological Research, 23 (4): 729-734.

CUÉLlAR, L. \& M. C. CUÉLLAR. 2000. Evolution de l'aphanomycose et repeuplements avec l'écrevisse signal (Pacifastacus leniusculus) en Espagne. L'Astaciculteur de France, 65: 2-9.

DANA, E. D., J. LÓPEZ SANTIAGO, J. GARCÍA DE LOMAS, D. GARCÍA-OCAÑA, V. GÁMEZ \& F. ORTEGA. 2010. Long-term management of the invasive Pacifastacus leniusculus (Dana, 1852) in a small mountain stream. Aquatic Invasions, 5 (3): 317-322.

DANA, E. D., J. GARCÍA DE LOMAS, R. GONZÁLEZ \& F. ORTEGA. 2011. Effectiveness of dam construction to contain the invasive crayfish Procambarus clarkii in a Mediterranean mountain stream. Ecological Engineering, 37 (11): 16071613.

DÍAZ DE TUESTA, A. M., M. P. GEIJO MARTÍNEZ, J. DIMAS NÚÑEZ, F. J. DÍAZ DE TUESTA, C. R. HERRANZ \& E. VAL PÉREZ. 2001.
Brote epidémico de tularemia en la provincia de Cuenca en relación con la manipulación de cangrejos. Revista Clínica Española, 201 (7), 385-389.

DIÉGUEZ-URIBEONDO, J., C. TEMINO \& J. L. MÚZQUIZ. 1997. The crayfish plague fungus (Aphanomyces astaci) in Spain. Bulletin Français de la Pêche et de la Pisciculture, 347: 753-763.

DIÉGUEZ-URIBEONDO, J., F. ROYO, C. SOUTYGROSSET, A. ROPIQUET \& F. GRANDJEAN. 2008. Low genetic variability of the white-clawed crayfish in the Iberian Peninsula: its origin and management implications. Aquatic Conservation: Marine and Freshwater Ecosystems, 18: 19-31.

DUNN, J. C., H. E. MCCLYMONT, M. CHRISTMAS \& A. M. DUNN. 2009. Competition and parasitism in the native White Clawed Crayfish Austropotamobius pallipes and the invasive Signal Crayfish Pacifastacus leniusculus in the UK. Biological Invasions, 11 (2): 315-324.

EDGERTON, B. F., L. H. EVANS, F. J. STEPHENS \& R. M. OVERSTREET. 2002. Synopsis of freshwater crayfish diseases and commensal organisms. Aquaculture, 206 (1-2): 57-135.

FAO. 2012. FAO Fisheries and Aquaculture Department Database <http://www.fao.org/fishery/statistics/en>. Downloaded on 02 June 2012.

FRATINI, S., S. ZACCARA, S. BARBARESI, F. GRANDJEAN, C. SOUTY-GROSSET, G. CROSA \& F. GHERARDI. 2005. Phylogeography of the threatened crayfish (genus Austropotamobius) in Italy: implications for its taxonomy and conservation. Heredity, 94 (1): 108-118.

FREEMAN, M. A., J. F. TURNBULL \& W. E. YEOMANS. 2007. Prospects for the control of nonnative crayfish in Scotland. Institute of Aquaculture, University of Stirling, Scotland.

GARCÍA-BERTHOU, E., D. BOIX \& M. CLAVERO. 2007. Non-indigenous animal species naturalized in Iberian inland waters. In: Biological invaders in inland waters: Profiles, distribution, and threats. F. Gherardi (ed.): 123-140. Springer. Dordrecht, The Netherlands.

GEIGER, W., P. ALCORLO, A. BALTANA \& C. MONTES. 2005. Impact of an introduced Crustacean on the trophic webs of Mediterranean wetlands. Biological Invasions, 7: 49-73.

GHERARDI, F. 2007. Understanding the impact of invasive crayfish. In: Biological invaders in inland waters: Profiles, distribution and threats. F. Gherardi (ed.): 507-542. Springer. Dordrecht, The Netherlands. 
GHIA, D., P. A. NARDI, A. NEGRI, F. BERNINI, A. BONARDI, G. FEA \& M. SPAIRANI. 2006. Syntopy of A. pallipes and A. italicus. Genetic and Morphometrical Investigations. Bulletin Français de la Pêche et de la Pisciculture, 380-381: 10011018.

GRANDJEAN, F., D. J. HARRIS, C. SOUTY-GROSSET \& K. A. CRANDALL. 2000. Systematics of the European endangered crayfish species, Austropotamobius pallipes (Decapoda: Astacidae). Journal of Crustacean Biology, 20 (3): 522-529.

GRANDJEAN, F., M. FRELON-RAIMOND \& C. SOUTY-GROSSET. 2002. Compilation of molecular data for the phylogeny of the genus Austropotamobius: one species or several? Bulletin Français de la Pêche et de la Pisciculture, 367: 671-680.

HOLDICH, D. M., J. D. REYNOLDS, C. SOUTYGROSSET \& P. J. SIBLEY. 2009. A review of the ever increasing threat to European crayfish from non-indigenous crayfish species. Knowledge and Management of Aquatic Ecosystems, 11: 394-395.

ILHÉU, M., J. M. BERNARDO \& S. FERNANDES. 2007. Predation of invasive crayfish on aquatic vertebrates: the effect of Procambarus clarkii on fish assemblages in Mediterranean temporary streams. In: Biological invaders in inland waters: Profiles, distribution, and threats. F. Gherardi (ed.): $543-$ 558. Springer. Dordrecht, The Netherlands.

ISSG. 2011. Global Invasive Species Database. <http:// www.issg.org/database/>. Downloaded on 10 December 2011.

IUCN. 2011. IUCN Red List of Threatened Species. Version 2011.2. <http://www.iucnredlist.org>. Downloaded on 10 November 2011.

JOHNSEN, S. I. \& T. TAUGBØL. 2010. NOBANIS - Invasive Alien Species Fact Sheet-Pacifastacus leniusculus. From: Online Database of the North European and Baltic Network on Invasive Alien Species-NOBANIS www.nobanis.org, Downloaded on 09 March 2012.

LARSON, E. R. \& J. D. OLDEN. 2011. State of Crayfish in the Pacific Northwest. Fisheries, 36: 60-71.

LONGSHAW, M. 2011. Diseases of crayfish: a review. Journal of invertebrate pathology, 106 (1): 54-70.

LOWE, S., M. BROWNE, S. BOUDJELAS \& M. DE POORTER. 2000. 100 of the world's worst invasive species. A selection from the global invasive species database. Invasive Species Specialist Group (ISSG, IUCN). Aliens, 12: 1-12.
MADOZ, P. 1845-1850. Diccionario geográficoestadístico-Histórico de España y sus posesiones de ultramar. Santander (ed.). Facsímil, Ámbito Ediciones, Valladolid.

MALDONADO, I., F. J. GALINDO, F. ARANDA \& B. NEBOT. 2008. Historia y evolución en la distribución del cangrejo de río autóctono en Andalucía y resto de España. Interpretación en base a la caracterización genética disponible para las poblaciones ibéricas. Actas XIV Congreso Ibérico Limnología, p. 98. Huelva, Spain.

MARCHI, M., S. E. JØRGENSEN, E. BÉCARES, I. CORSI, N. MARCHETTINI \& S. BASTIANONI. 2011. Dynamic model of Lake Chozas (León, NW Spain). Decrease in eco-exergy from clear to turbid phase due to introduction of exotic crayfish. Ecological Modelling, 222 (16): 3002-3010.

MATALLANAS, B., M. D. OCHANDO, A. VIVERO, B. BEROIZ, F. ALONSO \& C. CALLEJAS. 2011. Mitochondrial DNA variability in Spanish populations of A. italicus inferred from the analysis of a COI region. Knowledge and Management of Aquatic Ecosystems, 401: 30.

MATALLANAS, B., C. CALLEJAS \& M. D. OCHANDO. 2012. A genetic approach to Spanish populations of the threatened Austropotamobius italicus located at three different scenarios. The Scientific World Journal, 2012: 975930.

MCALAIN, W. R. \& R. P. ROMAIRE. 2007. Cultured Aquatic Species Information Programme. Procambarus clarkii. Cultured Aquatic Species Information Programme. In: FAO Fisheries and Aquaculture Department [online]. <http://www.fao. org/fishery/culturedspecies/Procambarus clarkii/ en>. Downloaded on 20 December 2011.

OIDTMANN, B., E. HEITZ, D. ROGERS \& R. W. HOFFMANN. 2002. Transmission of crayfish plague. Disease of Aquatic Organisms, 52: 159-167.

OSCOZ, J., M. PARDOS \& C. DURÁN. 2008. Nuevos datos sobre la presencia de cangrejos alóctonos en la Cuenca del río Ebro. Gorosti-Cuaderno de Ciencias Naturales de Navarra, 19: 4-11.

OSCOZ, J., P. TOMÁS \& C. DURÁN. 2010. Review and new records of non-indigenous freshwater invertebrates in the Ebro River basin (Northeast Spain). Aquatic Invasions, 5: 263-284.

PEAY, S. \& P. D. HILEY. 2001. Eradication of Alien Crayfish. Phase II. Environment Agency Technical Report W1-037/TR1, Environment Agency, Bristol. 
PEAY, S., P. D. HILEY, P. COLLEN \& I. MARTIN. 2006. Biocide treatment of ponds in Scotland to eradicate signal crayfish. Bulletin Français de la Pêche et de la Pisciculture, 380-381: 1363-1379.

PEDRAZA-LARA, C., F. ALDA, S. CARRANZA \& I. DOADRIO. 2010. Mitochondrial DNA structure of the Iberian populations of the white-clawed crayfish, Austropotamobius italicus italicus (Faxon, 1914). Molecular phylogenetics and evolution, 57 (1): 327-342.

RODRÍGUEZ, C. F., E. BÉCARES, M. FERNÁNDEZ-ALÁEZ \& C. FERNANDEZ-ALÁEZ. 2005. Loss of diversity and degradation of wetlands as a result of introducing exotic crayfish. Biological Invasions, 7: 75-85.

SCALICI, M., S. CHIESA, F. GHERARDI, M. RUFFINI, G. GIBERTINI \& F. N. MARZANO. 2009. The new threat to Italian inland waters from the alien crayfish "gang": the Australian Cherax destructor (Clark, 1936). Hydrobiologia, 632: 341-345.

SCHULZ, H. K. \& F. GRANDJEAN. 2005. Improving the taxonomy of European crayfish for a better conservation. Bulletin Français de la Pêche et de la Pisciculture, 376-377: 829-836.
SOUTY-GROSSET, C., D. M. HOLDICH, P. Y. NOËL, J. D. REYNOLDS \& P. HAFFNER. 2006. Atlas of Crayfish in Europe. Muséum national d'Histoire naturelle. Patrimoines naturels, 64. Paris.

STEBBING, P. D., G. J. WATSON, M. G. BENTLEY, D. FRASER, R. JENNINGS, S. P. RUSHTON \& P. J. SIBLEY. 2003. Reducing the threat: the potential use of pheromones to control invasive signal crayfish. Bulletin Français de la Pêche et de la Pisciculture, 370-371: 219-224.

TRONTELJ, P., Y. MACHINO \& B. SKET. 2005. Phylogenetic and phylogeographic relationships in the crayfish genus Austropotamobius inferred from mitochondrial COI gene sequences. Molecular Phylogenetics and Evolution, 34 (1): 212-226.

WITHNALL, F. 2000. Biology of Yabbies (Cherax destructor). Aquaculture notes. Department of Natural Resources and Environment 2002. Melbourne (Victoria), 1-4.

ZACCARA, S., F. STEFANI, P. GALLI, P. A. NARDI \& G. CROSA. 2004. Taxonomic implications in conservation management of white-clawed crayfish (Austropotamobius pallipes) (Decapoda, Astacidae) in Northern Italy. Biological Conservation, 120 (1): 1-10. 
